\title{
PENGARUH PELAKSANAAN KUALITAS AUDIT DAN PROPORSI DEWAN KOMISARIS INDEPENDEN TERHADAP KINERJA KEUANGAN PERUSAHAAN PROPERTY DAN REAL ESTATE DI BURSA EFEK INDONESIA
}

\author{
Ningsih ${ }^{1)}$, Aminar Sutra Dewi ${ }^{2)}$ \\ ${ }^{1,2)}$ Sekolah Tinggi Ilmu Ekonomi KBP \\ Email $^{1)}$ : ningsih2196@gmail.com \\ Email $^{2)}$ : aminarsutradewi@akbpstie.ac.id
}

\begin{abstract}
The decline in stock prices of property and real estate firms resulted from the government's policy of high loan interest has not affected the property sector and real estate. This study aims to examine the effect of Good Corporate Governance implementation that is the quality of auditor (KA) to financial performance and proportion of independent board of commissioner (PDKI) to company financial performance. This research uses purposive sampling method that is sampling technique which refers to certain criteria. Based on predetermined criteria, 23 companies will be selected as research samples in 2012 until 2016. The method of analysis used is quantitative method, with classical assumption test and panel data regression analysis. From the three tests obtained the best model is Fixed Effect Model (FEM). The results of this study indicate that audit quality has positive and insignificant effect on financial performance as reflected on return on equity. While the proportion of independent board of commissioners has a negative and significant impact on financial performance as reflected in return on equity.
\end{abstract}

Keywords: audit quality, proportion of independent board of commissioners, and financial performance

\begin{abstract}
ABSTRAK
Menurunnya harga saham perusahaan property dan real estate diakibatkan oleh kebijakan pemerintah yaitu bunga kredit masih tinggi belum berpengaruh terhadap sektor property dan real estate. Penelitian ini bertujuan untuk menguji pengaruh pelaksanaan Good Corporate Governance yaitu kualitas auditor (KA) terhadap kinerja keuangan dan proporsi dewan komisaris independen (PDKI) terhadap kinerja keuangan perusahaan. Penelitian ini menggunakan metode purposive sampling yaitu teknik pengambilan sampel yang mengacu pada kriteria-kriteria tertentu. Berdasarkan kriteria yang telah ditetapkan maka diperoleh 23 perusahaan yang akan dijadikan sampel penelitian pada periode 2012 sampai dengan 2016. Metode analisis yang digunakan yaitu metode kuantitatif, dengan uji asumsi klasik dan analisis regresi data panel. Dari ketiga uji diperoleh model terbaik adalah Fixed Effect Model (FEM). Hasil penelitian ini menunjukkan bahwa kualitas audit berpengaruh positif dan tidak signifikan terhadap kinerja keuangan yang tercermin pada return on equity. Sedangkan proporsi dewan komisaris independen berpengaruh negatif dan signifikan terhadap kinerja keuangan yang tercermin pada return on equity.
\end{abstract}

Kata kunci: kualitas audit, proporsi dewan komisaris independen, dan kinerja keuangan 


\section{PENDAHULUAN}

Kinerja perusahaan merupakan faktor penting yang harus diperhatikan para investor sebelum melakukan investasi. Oleh karena itu, kinerja dalam perusahaan/instansi harus terus ditingkatkan. Kinerja keuangan adalah cerminan dari seberapa baik pengelolaan perusahaan yang mengacu pada laporan keuangan yang sudah dipublikasikan pada suatu periode tertentu yang biasanya diukur dari aspek kecukupan modal, likuiditas dan profitabilitas (Aziz \& Hartono, 2017). Jadi, kinerja keuangan perusahaan menganalisis tingkat keberhasilan untuk melihat sejauh mana perusahaan telah melaksanakan dengan menerapkan peraturan pelaksanaan secara tepat. Penilaian kinerja suatu perusahaan bisa digunakan sebagai alat untuk melakukan analisis yang tergantung dari pemikiran pemilik, kreditur, dan manajer.

Kebijakan dan keputusan para investor dalam berinvestasi lebih dipengaruhi oleh rasio profitabilitas yang dimiliki oleh suatu perusahaan dibandingkan dengan rasio lainnya, karena investor beranggapan bahwa profitabilitas bisa memberikan gambaran tentang tingkat keuntungan yang akan diperoleh investor dari investasinya.Tujuan yang dicapai untuk menarik stakeholders untuk dapat membantu menunjang operasional merupakan peningkatan kinerja dalam perusahaan. Penilaian kinerja keuangan yang dilakukan perusahaan dan pemegang saham salah satunya adalah return on equity. Untuk mengetahui besarnya nilai return on equity, maka perusahaan harus menganalisis kembali bagaimana kinerja keuangan dalam perusahaan pada periode tertentu. Semakin banyak return yang perusahaan hasilkan maka kedudukan pemilik perusahaan juga semakin baik (Djazilah \& Kurnia, 2016).

Menurut Hasanah, dkk (2017) semakin banyak perusahaan property dan real estate yang tercatat di Bursa Efek Indonesia maka persaingan antar perusahaan juga akan semakin ketat, sehingga mendorong perusahaan dalam memperbaiki kinerja keuangan. Perkembangan industri Property dan Real Estate akan semakin pesat dan meningkat setiap tahunnya, itu dikarenakan tanah memiliki ketersediaan yang bersifat tetap sedangkan setiap tahunnya penduduk Indonesia terus mengalami peningkatan. Ditambah lagi saat pemerintahan Presiden Jokowi, Indonesia terus melakukan pembangunan sarana prasarana untuk menunjang laju perekonomian. Peningkatan kualitas hidup, bagi masyarakat berpendapatan rendah mendapatkan rumah menjadi perioritas utama bagi pemerintah. Sebagian pengembang menduga bahwa 2017 ini adalah tahun kebangkitan sektor property tidak sepenuhnya tepat. Kebijakan ekonomi seperti penurunan bunga kredit, relaksasi loan to value, potongan pajak penjualan, deregulasi perizinan, hingga amnesti pajak merupakan stimulus yang diberikan pemerintah untuk mendorong pertumbuhan. Tetapi tidak berjalan dengan mulus bahkan kondisi properti 2017 masih berjalan dengan lambat.

Masalah penelitian ini yaitu menurunnya harga saham perusahaan property dan real estate diakibatkan oleh kebijakan pemerintah yaitu bunga kredit masih tinggi belum berpengaruh terhadap sektor property dan real estate. Karena dana yang digunakan untuk investasi tidak selalu signifikan sebab imbal balik dari investasi properti belum cukup menarik. Harga saham yang menurun mempengaruhi para investor tidak berinvestasi pada sektor property dan real 
estate, sehingga mengakibatkan penurunan penjualan. Penurunan penjualan akan mempengaruhi kinerja keuangan perusahaan, apabila penjualan menurun maka kinerja keuangan perusahaan menjadi kurang baik.

Good Corporate Governance memberikan pengaruh terhadap kinerja keuangan perusahaan. Good Corporate Governance itu sendiri ialah suatu konsep yang didasarkan pada teori keagenan, diharapkan bisa berfungsi sebagai alat untuk meyakinan para investor bahwa mereka akan memperoleh keuntungan dari dana yang telah diinvestasikan. Pelaksanaan corporate governance bermanfaat untuk meningkatkan kinerja perusahaan dari proses pengambilan keputusan yang lebih tepat, meningkatkan operasional perusahaan secara efisien juga harus memberikan pelayanan lebih kepada stakeholders(Kusdiyanto \& Kusmaningrum, 2015). Penelitian ini berfungsi untuk menguji pengaruh pelaksanaan Good Corporate Governance (GCG) yaitu kualitas auditor (KA) dan proporsi dewan komisaris independen (PDKI) terhadap kinerja keuangan perusahaan.

Menurut Djazilah \& Kurnia (2016) beberapa penelitian menemukan bahwa perusahaan audit yang besar dengan reputasi yang tinggi dapat menghasikkan kualitas audit yang lebih baik, sehingga hasilnya dapat meningkatkan transparansi perusahaan dan corporate governance. Efektifnya fungsi pengawasan yang dilakukan oleh komite audit dapat meningkatkan kinerja keuangan. Kualitas audit ialah suatu kemungkinan dimana seorang auditor dapat menemukan dan melaporkan kesalahan pada sistem akuntansi kliennya. Auditor bisa menemukan salah saji tergantung pada kemampuan teknikal auditor sementara tindakan melaporkan salah saji tergantung pada independensi auditor tersebut. Kualitas audit sangatlah penting karena kualitas audit yang lebih baik akan menghasilkan laporan keuangan yang akurat dan dapat dipercaya sebagai dasar pengambilan keputusan (Hardiningsih, 2010). Laporan keuangan yang baik akan mempengaruhi kinerja keuangan semakin baik.

Beberapa penelitian terdahulu telah melakukan kajian secara empiris seperti yang dilakukan Hardiningsih (2010) mengenai pengaruh independensi, corporate governance, dan kualitas audit terhadap integritas laporan keuangan menunjukkan bahwa variabel kualitas audit tidak berpengaruh signifikan terhadap integritas laporan keuangan. Cenderung mengarah ke positif menunjukkan bahwa semakin baik tingkat kualitas audit berarti semakin baik keahlian auditor (spesialisasi) maka semakin baik juga tingkat integritas laporan keuangan, dan semakin baik juga laporan keuangan. Didukung oleh penelitian Susanti (2011) tentang pengaruh kualitas corporate governance, kualitas audit, dan earning management terhadap kinerja perusahaan. Dengan hasil bahwa kualitas audit berpengaruh secara negatif terhadap kinerja perusahaan. Berarti bahwa audit yang berkualitas akan menurunkan kinerja perusahaan. Sedangkan penelitian Setiawan (2015) tentang pengaruh independensi, kualitas audit dan mekanisme corporate terhadap integritas laporan keuangan perusahaan. Dengan hasil menunjukkan kualitas audit berpengaruh terhadap integritas laporan keuangan. Berdasrkan uraian diatas, hipotesis yang dapat dirumuskan adalah:

$\mathrm{H}_{0}=$ Kualitas Audit tidak memiliki pengaruh yang signifikan terhadap kinerja keuangan

$\mathrm{H}_{\mathrm{a}}=$ Kualitas Audit memiliki pengaruh yang signifikan terhadap kinerja keuangan 
Proporsi dewan komisaris independen merupakan anggota dewan komisaris yang tidak berafiliasi (berhubungan) dengan direksi, anggota dewan komisaris lainnya, pemegang saham pengendali, juga bebas dari hubungan bisnis lainnya yang bisa mempengaruhi kemampuannya untuk bertindak independen. Pengukuran variabel ini melalui persentase total komisaris independen terhadap jumlah seluruh anggota dewan komisaris (Djazilah \& Kurnia, 2016). Untuk melaksanakan fungsi monitoring agar tercipta perusahaan yang Good Corporate Governance yang mempunyai posisi terbaik adalah komisaris independen(Eva \& Artinah, 2016). Pengawasan dewan komisaris independen dilakukan untuk dapat meningkatkan kinerja manajer sehingga dapat memungkinkan kinerja perusahaan juga akan meningkat. Semakin besar proporsi komisaris independen maka semakin besar kekuatan (power) dewan komisaris dalam menekan manajemen agar kinerja perusahaan meningkat.

Penelitian-penelitian sebelumnya tentang pengaruh corporate governance terhadap kinerja keuangan mulai banyak dilakukan, seperti penelitian Djazilah \& Kurnia (2016) mengenai pengaruh mekanisme GCG dan pengungkapan CSR terhadap kinerja keuangan bahwa proporsi dewan komisaris independen mempunyai pengaruh signifikan terhadap kinerja keuangan tercermin pada return on equity. Didukung oleh penelitian Perdana, Putra \& Murni (2016) mengatakan bahwa dewan komisaris independen memiliki pengaruh positif terhadap kinerja keuangan perusahaan. Sedangkan penelitian Kusdiyanto \& Kusmaningrum, (2015)pengaruh good corporate governance dan laverage terhadap kinerja keuangan (studi pada perusahaan manufaktur yang tercatat di BEI 2013-2014) bahwa komisaris independen mempunyai pengaruh negatif signifikan terhadap kinerja keuangan. Berdasarkan uraian diatas, hipotesis yang dirumuskan dalam penelitian ini adalah:

$\mathrm{H}_{0}=$ Proporsi Dewan Komisaris Independen tidak memiliki pengaruh yang signifikan terhadap kinerja keuangan

$\mathrm{H}_{\mathrm{a}}=$ Proporsi Dewan Komisaris Independen memiliki pengaruh yang signifikan terhadap kinerja keuangan

\section{METODE PENELITIAN}

Jenis penelitian yang digunakan dalam penelitian adalah metode kuantitatif, disebut metode kuantitatif karena data penelitian berupa angka-angka dan analisis menggunakan statistik (Sugiyono, 2015:13).Dengan kata lain penelitian kuantitatif adalah penelitian yang dapat dinyatakan dengan angka dan dapat dihitung dengan menggunakan rumus-rumus tertentu.

Obyek penelitian adalah segala sesuatu yang menjadi pusat perhatian seseorang dalam melakukan sebuah penelitian (Sugiyono, 2015). Maka obyek penelitian ini adalah perusahaan Property dan Real Estate yang terdaftar di Bursa Efek Indonesia (BEI). Lokasi penelitian ini berada di Jl. Jend.Sudirman Kav 5253 Jakarta Selatan 12190, Indonesia.

Populasi adalah wilayah secara umum atau generalisasi yang terdapat subjek/objek yang mempunyai kuantitas tertentu yang ditetapkan oleh peneliti untuk dipelajari dan kemudian ditarik kesimpulannya (Sugiyono, 2015:92).Jadi populasi merupakan seluruh karakteristik atau sifat yang dimiliki oleh subjek atau objek yang diteliti.Populasi yang akan diamati dalam penelitian ini adalah 
perusahaan property dan real estate yang terdaftar di BEI selama tahun 2012 sampai 2016, dengan jumlah populasi sebanyak 56 perusahaan yang telah go public. Sampel ialah bagian dari jumlah dan ciri khas yang dimiliki oleh populasi yang akan diteliti. Sampel dalam penelitian ini diperoleh dengan menggunakan teknik purposive samplingyaitu teknik pengambilan sampel yang mengacu pada kriteria-kriteria tertentu. Berdasarkan kriteria yang telah ditetapkan diatas maka diperoleh 23 perusahaan yang akan dijadikan sampel penelitian.

Dalam pengumpulkan data penelitian ini, maka dilakukanlah teknik yang dinamakan dokumentasi.Teknik dokumentasi yaitu teknik pengumpulan data dengan pengumpulan dokumen-dokumen yang diperlukan dari internet, bukubuku literatur serta penelitian terdahulu. Teknik dokumentasi diperoleh dari datadata yang dipublikasikan oleh perusahaan property dan real estate yang terdaftar di Bursa Efek Indonesia melalui situs resmi BEI yaitu, www.idx.co.id.

\section{Definisi Operasional}

Variabel yang digunakan dalam penelitian ini adalah variabel bebas (independent variable) dan variabel terikat (dependent variable) (Sugiyono, 2015).Adapun yang menjadi variabel bebas dalam penelitian ini adalah kualitas audit dan proporsi dewan komisaris.Variabel terikat yang digunakan dalam penelitian ini adalah kinerja keuangan perusahaan yang diproksikan dengan Return On Equity (ROE).

Tabel 1

Definisi Operasional Perusahaan

\begin{tabular}{|c|c|c|c|}
\hline Variabel & Definisi & Pengukuran & Sumber \\
\hline $\begin{array}{l}\text { Kinerja } \\
\text { Keuangan } \\
(\mathrm{ROE})\end{array}$ & $\begin{array}{l}\text { Return On Equity } \\
\text { adalah } \\
\text { kemampuan } \\
\text { perusahaan dalam } \\
\text { menghasilkan } \\
\text { keuntungan } \\
\text { dengan modal } \\
\text { sendiri yang } \\
\text { dimiliki. }\end{array}$ & $R O E=\frac{E A T}{\text { ModalSendiri }} \times 100 \%$ & $\begin{array}{l}\text { (Sutrisno } \\
\text {, 2012) }\end{array}$ \\
\hline $\begin{array}{l}\text { Kualitas } \\
\text { Audit }\end{array}$ & $\begin{array}{l}\text { Kualitas audit } \\
\text { sebagai } \\
\text { probabilitas } \\
\text { gabungan untuk } \\
\text { mendeteksi dan } \\
\text { melaporkan } \\
\text { kesalahan yang } \\
\text { material dalam } \\
\text { laporan } \\
\text { keuangan. }\end{array}$ & $\begin{array}{c}\text { Jumlah seluruh auditor yang ada } \\
\text { dalam perusahaan baik internal } \\
\text { maupun eksternal. }\end{array}$ & $\begin{array}{l}\text { (Christia } \\
\text { ni \& } \\
\text { Nugraha } \\
\text { nti, } \\
2014)\end{array}$ \\
\hline
\end{tabular}




\begin{tabular}{|c|c|c|c|}
\hline $\begin{array}{l}\text { Proporsi } \\
\text { Dewan } \\
\text { Komisaris } \\
\text { Independe } \\
\text { n }\end{array}$ & $\begin{array}{l}\text { Dewan komisaris } \\
\text { independen } \\
\text { merupakan pihak } \\
\text { yang tidak } \\
\text { diperkenankan } \\
\text { memiliki } \\
\text { hubungan apapun } \\
\text { yang berkaitan } \\
\text { dengan } \\
\text { pengelolaan } \\
\text { perusahaan. }\end{array}$ & $\begin{array}{l}\text { PDKI } \\
=\frac{\text { KomisarisIndependen }}{\text { TotalDewanKomisaris }} \times 100 \%\end{array}$ & $\begin{array}{l}\text { (Aziz \& } \\
\text { Hartono, } \\
\text { 2017) }\end{array}$ \\
\hline
\end{tabular}

\section{Teknik Analisis Data \\ Statistik Deskriptif}

Statistik deskriptif ialah statistik yang digunakan untuk memberikan deskripsi atau gambaran mengenai obyek yang diteliti lewat data sampel ataupun populasi sebagaimana adanya, dengan tidak melakukan analisis maupun membuat kesimpulan yang berlaku untuk umum (Sugiyono, 2015:61). Pada statistik deskriptif ini cara penyajian data dilakukan menggunakan tabel biasa kemudian dilakukan penjelasan kelompok melalui nilai maximum, minimum, median, mean dan standar deviasi.

\section{Uji Asumsi Klasik Uji Normalitas}

Uji normalitas data bertujuanuntuk mengetahui apakah sampel penelitian yang diambil telah memenuhi kriteria sebaran atau sudah terdistribusi dengan normal atau tidak(Fahruri, 2017). Dengan menggunakan uji Jarque-Bera, uji ini dilakukan untuk mengetahui apakah data sudah terdistribusi dengan normal atau tidak, dimana $\alpha=0,05$ yang digunakan sebagai tingkat signifikansinya. Jika signifikansi yang dihasilkan $>5 \%$ maka disimpulkan data tersebut sudah terdistribusi dengan normal. Namun jika signifikansi yang dihasilkan $<5 \%$ maka data tidak terdistribusi secara normal(Winarno, 2015b).

\section{Uji Multikolinearitas}

Multikolinearitas ialah kondisi dimana terdapat hubungan linier antar sesama variabel independen (Winarno, 2015).Fungsi dari uji ini ialah untuk menguji apakah terdapat korelasi antara sesama variabel independen didalam model regresi.Suatu model regresi dikatakan baik apabila tidak ada terdapat korelasi yang tinggi diantara variabel bebas.Jika nilai $\mathrm{F}_{\text {hitung }}<\mathrm{F}_{\text {kritis }}$ pada alpha dan kebebasan tertentu (kecil dari 80\%) maka model bebas dari gejala multikolienaritas.

\section{Uji Heteroskedastisitas}

Uji heteroskedasitisitas bertujuan menguji apakah dalam model regresi terjadi ketidaksamaan variance dari residual satu pengamatan ke pengamatan lain (Fahruri, 2017). Dengan kata lain, untuk melihat ada atau tidak pengaruh antara variable bebas dengan residual (error). Deteksi ada tidaknya heteroskedastisitas 
dapat diuji menggunakan uji Glejser. Jika nilai signifikan antara variabel independen dengan absolute residual lebih dari alpha (5\%) maka tidak terdapat gejala heteroskedastisitas dan sebaliknya.

\section{Uji Pemilihan Model}

Terdapat tiga metode dalam regresi data panel yaitu metode Common Effect Model(CEM), Fixed Effect Model (FEM), Random Effect Model (REM).

1. Metode Common Effect Model (CEM)

Metode ini menggambarkan data cross section dengan time series dan menggunakan metode OLS untuk mengestimasi model data panel tersebut. Model ini merupakan model paling sederhana dibandingkan dengan kedua model lainnya. Model ini tidak dapat membedakan varians antara silang dan bukan bervariasi secara random.

2. Metode Fixed Effect Model (FEM)

Merupakan model dengan intercept berbeda-beda untuk setiap subject (cross section), tetapi setiap subjek tidak berubah seiring waktu. Model ini mengasumsikan bahwa intercept adalah berbeda setiap subjek lainnya digunakan variabel dummy. Model ini sering disebut dengan model Least Square Dummy Variabel(LSDV).

3. Metode Random Effect Model (REM)

Metode ini disebabkan oleh variasi dalam nilai dan arah hubungan antara subjek diasumsikan random yang dispesifikasikan dalam bentuk residual. Model ini mengestimasikan data panel yang variabel residual diduga memiliki hubungan antar subjek. Model ini digunakan untuk mengatasi kelemahan model Fixed Effectyang menggunakan variabel dummy. Metode analisis data panel dengan metode random effect harus memenuhi persyaratan yaitu jumlah cross section lebih besar dari pada jumlah variabel penelitian.

\section{Analisis Regresi Data Panel} berikut:

Persamaan regresi yang digunakan dalam analisis data panel adalah sebagai Dimana :

$$
\mathrm{ROE}_{\mathrm{it}}=\alpha+\beta_{1} \mathrm{KA}_{\mathrm{it}+} \beta_{2} \mathrm{PDKI}_{\mathrm{it}}+\mathrm{e}
$$

$\mathrm{ROE}=$ Return On Equity pada waktu $\mathrm{t}$

$\mathrm{KA}_{\mathrm{it}}=$ Kualitas Audit pada waktu t

$\mathrm{PDKI}_{\mathrm{it}}=$ Proporsi Dewan Komisaris Independen pada waktu $\mathrm{t}$

$\alpha=$ Intercept

$\beta_{1}$ dan $\beta_{2}=$ Koefisien Regresi

$\mathrm{e}=$ Standar Error

\section{Uji Hipotesis}

Hipotesis merupakan jawaban sementara terhadap rumusan masalah penelitian, dimana rumusan masalah penelitian telah dinyatakan dalam bentuk kalimat pertanyaan (Sugiyono, 2015). Jadi, hipotesis juga dapat dinyatakan sebagai jawaban teoritis terhadap rumusan masalah penelitian, belum jawaban yang empirik. Uji ini digunakan untuk menguji pengaruh variabel-variabel 
independen. Pengujian dilakukan dengan menggunakan significance level $(\alpha=$ 0,05) atau 5\% (Rahmawati \& Asyikin, 2016).

Kriteria untuk menolak atau menerima hipotesis, pada tingkat kesalahan yang digunakan sebesar $5 \%$ atau 0,05 pada taraf signifikasi $95 \%$.

a. Jika thitung $>t_{\text {tabel }}$ maka $\mathrm{HO}$ diterima dan menolak Ha yang artinya koefisien korelasi berganda yang dihitung signifikan.

b. Jikat ${ }_{\text {hitung }}>\mathrm{t}_{\text {tabel }}$ maka $\mathrm{H} 0$ ditolak dan menerima Ha, yang artinya koefisien korelasi berganda yang dihitung tingkat signifikan dan menunjukkan terdapat pengaruh secara parsial.

\section{HASIL PENELITIAN DAN PEMBAHASAN}

Setelah data dianalisis menggunakan metode kuantitatif, dengan uji asumsi klasik dan analisis regresi data panel melalui aplikasi Eviews versi 8, maka diperoleh hasil penelitian diantaranya :

\section{Analisis Statistik Deskriptif}

\section{Tabel 2}

\section{Hasil Uji Statistik Deskriptif}

Descriptive Statistics

\begin{tabular}{lccc}
\hline & $\begin{array}{c}\text { Return On Equity } \\
(\mathrm{Y})\end{array}$ & $\begin{array}{c}\text { Kualitas Audit } \\
(\mathrm{X} 1)\end{array}$ & $\begin{array}{c}\text { Proporsi Dewan } \\
\text { Komisaris Independen } \\
(\mathrm{X} 2)\end{array}$ \\
\hline Observation & 115 & 115 & 115 \\
Minimum & 0.14 & 2.00 & 0.20 \\
Maximum & 52.43 & 5.00 & 0.83 \\
Mean & 13.3069 & 3.9304 & 0.3964 \\
Std. Deviation & 9.40348 & 0.84523 & 0.11284 \\
\hline
\end{tabular}

Sumber : Output EViews

Tabel 2 di atas menunjukkan bahwa jumlah observasi pada penelitian ini adalah 115 data. Data Return On Equity adalah kinerja keuangan menunjukkan bahwa nilai rata-rata (mean) 13,3069 dengan tingkat penyimpangan atau standar deviasi 9,40348. Nilai terendah (minimum) sebesar 0,14\% yang berada pada perusahaan Bekasi Asri Pemula Tbk. [S] pada tahun 2016. Sedangkan nilai tertinggi (maxsimum) sebesar 52,43\% yaitu pada perusahaan Modernland Realty Tbk. [S] pada tahun 2013. Dengan demikian data variabel Return On Equtydikatakan cukup baik. Hal ini dikarenakan simpangan data relatif kecil dimana nilai standar deviasi lebih kecil dari pada nilai mean.

Data kualitas audit menunjukkan bahwa nilai rata-rata (mean) 3,9304 minimum 2 orang yaitu pada perusahaan Megapolitan Development Tbk., maksimum 5 orang salah satunya yaitu pada perusahaan Agung Podomoro Tbk., dengan standar deviasi 0,84523. Dengan demikian data kualitas audit dikatakan cukup baik. Hal ini dikarenakan simpangan data relatif kecil dimana nilai standar deviasi lebih kecil dari pada nilai mean. Data Proporsi Dewan Komisaris Independen menunjukkan bahwa nilai rata-rata (mean) sebesar 0.9364 atau 93,64\% dengan tingkat penyimpangan 0,11284 atau $11,28 \%$. Nilai tertinggi sebesar 0,83 atau 83\% yaitu pada perusahaan Lippo Karawaci Tbk. [S] pada tahun 
2016. Nilai terendah sebesar 0,20 atau $20 \%$ yaitu pada perusahaan Gowa Makassar Tourism Development Tbk. [S] pada tahun 2012. Dengan demikian data proporsi dewan komisaris independen dikatakan cukup baik, karena simpangan data relatif kecil dimana nilai standar deviasi lebih kecil dari pada mean.

\section{Uji Asumsi Klasik}

\section{Uji Normalitas}

Bertujuan untuk menggambarkan seberapa jauh pengaruh variabel independen secara bersama-sama dalam menerangkan variable dependen dalam penelitian telah terdistribusi normal atau tidak normal(Fahruri, 2017).

\section{Grafik 1}

\section{Hasil Uji Normalitas}

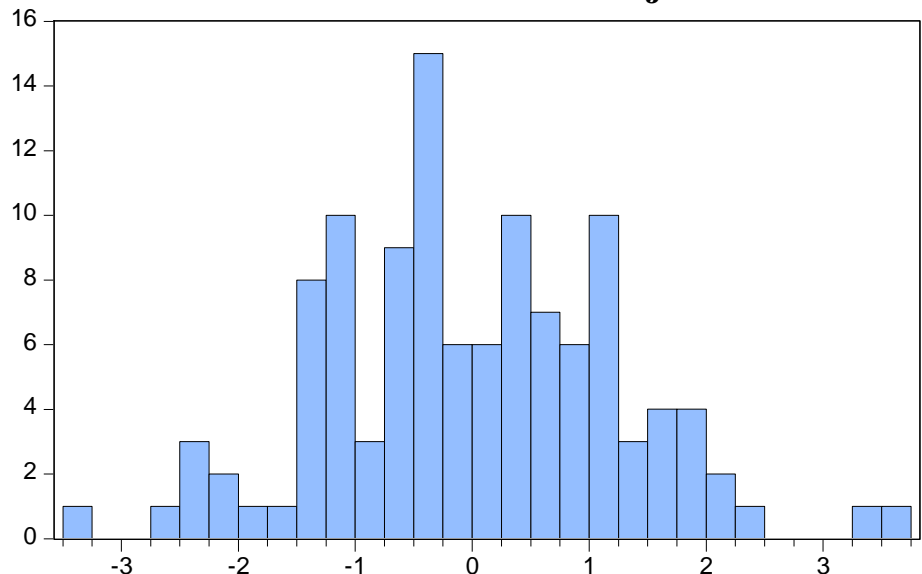

Series: Standardized Residuals Sample 20122016

Observations 115

Mean $\quad 6.72 \mathrm{e}-16$

Median $\quad-0.152887$

Maximum $\quad 3.582993$

Minimum $\quad-3.253760$

Std. Dev. $\quad 1.244606$

Skewness $\quad 0.129536$

Kurtosis $\quad 3.083411$

Jarque-Bera $\quad 0.354948$

Probability 0.837383

\section{Sumber : Output EViews}

Hasil uji normalitas dengan uji Jarque-Bera menunjukkan bahwa data telah terdistribusi secara normal. Hal ini terlihat dari nilai probabilitasberada diatas $5 \%$ dimana diperoleh nilai probability sebesar 0,84 >0,05.

\section{Uji Multikolinearitas}

Bertujuan untuk menguji apakah model regresi ditemukan adanya korelasi antar variabel bebas atau independent.

\section{Tabel 3}

Hasil Uji Multikoliniearitas

\begin{tabular}{llll}
\hline \multicolumn{1}{c}{ Variabel } & KA & PDKI & Keterangan \\
\hline KA & 1.000000 & 0.144209 & Bebas Multikolinearitas \\
PDKI & 0.144209 & 1.000000 & Bebas Multikolinearitas \\
\hline
\end{tabular}

Sumber: Output Eviews

Berdasarkan tabel 3 dapat disimpulkan bahwa model regresi tersebut bebas multikolinearitas. Hal ini ditunjukkan dengan semua variabel independen bahwa nilai korelasi matrik variabel independen sebesar 0.14 dimana kecil dari 0.8 (80\%), maka diperoleh kesimpulan bahwa data tersebut bebas dari multikolinearitas. 


\section{Uji Heteroskedastisitas}

Bertujuan untuk membuktikan apakah dalam model regresi terjadi ketidaksamaan varian dari residual satu pengamatan ke pengamatan lain. Model regresi yang baik adalah model yang tidak terjadi heteroskedastisitas. Deteksi ada tidaknya heteroskedastisitas dapat diuji menggunakan uji Glejser.

\section{Tabel 4}

Hasil Uji Heteroskedastisitas

\begin{tabular}{lcc}
\hline \multicolumn{1}{c}{ Variabel } & Sig. & Keterangan \\
\hline $\begin{array}{l}\text { Kualita Audit } \\
\text { Proporsi Dewan Komisaris }\end{array}$ & 0.998 & Bebas Heteroskedastisitas \\
Independen & 0.192 & Bebas Heteroskedastisitas \\
\hline
\end{tabular}

Sumber : Output EViews

Berdasarkan hasil pengujian pada tabel 4 menunjukkan bahwa semua variabel independen dalam penelitian ini tidak terjadi heteroskedastisitas, karena nilai signifikan antara variabel independen dengan absolut residual masingmasing lebih dari alpha (5\%). Nilai signifikan yang dihasilkan variabel kualitas audit adalah 0,998 dan nilai signifikan yang dihasilkan variabel proporsi dewan komisaris independen adalah 0,192 .

\section{Analisis Regresi Data Panel}

Tabel 5

\section{Hasil Common Effect Model}

Dependent Variable: ROE

Method: Panel Least Squares

Date: 03/02/18 Time: 13:27

Sample: 20122016

Periods included: 5

Cross-sections included: 23

Total panel (balanced) observations: 115

\begin{tabular}{lrlll}
\hline \hline \multicolumn{1}{c}{ Variable } & Coefficient & Std. Error & t-Statistic & Prob. \\
\hline \hline \multicolumn{1}{c}{ C } & 1.687207 & 0.772423 & 2.184304 & 0.0310 \\
\multicolumn{1}{c}{ KA } & 0.000656 & 0.325751 & 0.002015 & 0.9984 \\
PDI & -1.107766 & 0.843428 & -1.313409 & 0.1917 \\
\hline \hline R-squared & 0.015479 & Mean dependent var & 0.997054 \\
Adjusted R-squared & -0.002102 & S.D. dependent var & 0.739058 \\
S.E. of regression & 0.739834 & Akaike info criterion & 2.260960 \\
Sum squared resid & 61.30377 & Schwarz criterion & 2.332567 \\
Log likelihood & -127.0052 & Hannan-Quinn criter. & 2.290025 \\
F-statistic & 0.880451 & Durbin-Watson stat & 1.728276 \\
Prob(F-statistic) & 0.417445 & & & \\
\hline
\end{tabular}

Sumber : Output EViews 
Berdasarkan tabel 5 menunjukkan bahwa nilai R-Square $\left(\mathrm{R}^{2}\right)$ sebesar $0,015479(1,5 \%)$, menjelaskan bahwa kemampuan variabel nilai panel menjelaskan kualitas audit dan proporsi dewan komisaris independen adalah $1,5 \% \%$ dan $98,5 \%$ dijelaskan oleh variabel lain yang tidak terdapat pada model. Koefisien probability t-statistic kualitas audit dan proporsi dewan komisaris independen keduanya tidak signifikan, karena besar dari alpha 5\%. Dimana nilai probabilitas t-statistic kualitas audit $(0.998<0.05)$, dan probabilitas t-statistic proporsi dewan komisaris independen $(0.192>0.05)$.

\section{Tabel 6 \\ Hasil Fixed Effect Model}

Dependent Variable: ROE

Method: Panel Least Squares

Date: 03/02/18 Time: 13:28

Sample: 20122016

Periods included: 5

Cross-sections included: 23

Total panel (balanced) observations: 115

\begin{tabular}{lrlll}
\hline \hline \multicolumn{1}{c}{ Variable } & Coefficient & Std. Error & t-Statistic & Prob. \\
\hline \hline C & 1.450614 & 1.858031 & 0.780726 & 0.4370 \\
KA & 1.039752 & 0.737041 & 1.410712 & 0.1618 \\
PDKI & -4.009823 & 1.808207 & -2.217568 & 0.0291 \\
\hline \hline \multicolumn{5}{c}{ Effects Specification } \\
\hline \hline Cross-section fixed (dummy variables) & \\
\hline \hline & & & \\
R-squared & 0.283827 & Mean dependent var & 0.997054 \\
Adjusted R-squared & 0.092848 & S.D. dependent var & 0.739058 \\
S.E. of regression & 0.703913 & Akaike info criterion & 2.325335 \\
Sum squared resid & 44.59436 & Schwarz criterion & 2.922059 \\
Log likelihood & -108.7068 & Hannan-Quinn criter. & 2.567542 \\
F-statistic & 1.486168 & Durbin-Watson stat & 2.210473 \\
Prob(F-statistic) & 0.093256 & & \\
\hline \hline
\end{tabular}

Sumber: Output EViews

Berdasarkan tabel 6 dapat diketahui bahwa nilai R-Square $\left(\mathrm{R}^{2}\right)$ sebesar 0.283827 (28\%), menjelaskan bahwa kemampuan variabel nilai panel menjelaskan kualitas audit dan proporsi dewan komisaris independen adalah 28\% dan $72 \%$ dijelaskan oleh variabel lain yang tidak terdapat pada model. Koefisien probability t-statistic kualitas audit tidak signifikan karena besar dari alpha 5\% $(0,16>0,05)$. Sedangkan koefisien probability t-statistic proporsi dewan komisaris independen signifikan karena kecil dari alpha $5 \%(0,03<0,05)$. 


\section{Tabel 7 \\ Hasil Random Effect Model}

Dependent Variable: ROE

Method: Panel EGLS (Cross-section random effects)

Date: 03/02/18 Time: 13:28

Sample: 20122016

Periods included: 5

Cross-sections included: 23

Total panel (balanced) observations: 115

Swamy and Arora estimator of component variances

\begin{tabular}{|c|c|c|c|c|}
\hline Variable & Coefficient & Std. Error & $\mathrm{t}$-Statistic & Prob. \\
\hline $\mathrm{C}$ & 1.676919 & 0.841097 & 1.993729 & 0.0486 \\
\hline KA & 0.079610 & 0.352935 & 0.225565 & 0.8220 \\
\hline PDKI & -1.340590 & 0.910554 & -1.472280 & 0.1437 \\
\hline \multicolumn{5}{|c|}{ Effects Specification } \\
\hline & & & S.D. & Rho \\
\hline Cross-section randon & & & 0.196134 & 0.0720 \\
\hline Idiosyncratic random & & & 0.703913 & 0.9280 \\
\hline \multicolumn{5}{|c|}{ Weighted Statistics } \\
\hline R-squared & 0.018430 & \multirow{5}{*}{\multicolumn{2}{|c|}{$\begin{array}{l}\text { Mean dependent var } \\
\text { S.D. dependent var } \\
\text { Sum squared resid } \\
\text { Durbin-Watson stat }\end{array}$}} & 0.846243 \\
\hline Adjusted R-squared & 0.000902 & & & 0.715124 \\
\hline S.E. of regression & 0.714802 & & & 57.22546 \\
\hline F-statistic & 1.051456 & & & 1.819670 \\
\hline Prob(F-statistic) & 0.352852 & & & \\
\hline \multicolumn{5}{|c|}{ Unweighted Statistics } \\
\hline R-squared & 0.014441 & \multirow{2}{*}{\multicolumn{2}{|c|}{$\begin{array}{l}\text { Mean dependent var } \\
\text { Durbin-Watson stat }\end{array}$}} & 0.997054 \\
\hline Sum squared resid & 61.36841 & & & 1.721898 \\
\hline
\end{tabular}

Sumber : Output Eviews

Berdasarkan tabel 7 menunjukkan bahwa nilai R-Square $\left(\mathrm{R}^{2}\right)$ sebesar $0.018430(1,8 \%)$, menjelaskan bahwa kemampuan variabel nilai panel menjelaskan kualitas audit dan proporsi dewan komisaris independen adalah 1,8\% dan 98,2\% dijelaskan oleh variabel lain yang tidak terdapat pada model. Koefisien kualitas audit dan proporsi dewan komisaris independen sama-sama tidak signifikan karena probabilitas t-statistic kedua variabel tersebut besar dari alpha $5 \%(\mathrm{KA}=0.822>0.05$ dan $\mathrm{PDKI}=0.143>0.05)$.

\section{Regresi Data Panel Model Terbaik}

Dari ketiga uji yang telah dilakukan diperoleh model terbaik antara Common Effect Test, Fixed Effect Test dan Random Effect Test. Hasil estimasi 
menjelaskan bahwa masing-masing model memiliki nilai signifikansi berbeda. Dari pemilihan model tersebut model yang terbaik diantara ketiga model tersebut adalah Fixed Effect Testkarena memiliki nilai R-Square $\left(\mathrm{R}^{2}\right)$ tertinggi.

\section{Tabel 8}

Dependent Variable: ROE

\section{Hasil Fixed Effect Model}

Method: Panel Least Squares

Date: 03/02/18 Time: 13:28

Sample: 20122016

Periods included: 5

Cross-sections included: 23

Total panel (balanced) observations: 115

\begin{tabular}{crrrl}
\hline \hline Variable & Coefficient & Std. Error & t-Statistic & Prob. \\
\hline \hline C & 1.450614 & 1.858031 & 0.780726 & 0.4370 \\
KA & 1.039752 & 0.737041 & 1.410712 & 0.1618 \\
PDKI & -4.009823 & 1.808207 & -2.217568 & 0.0291 \\
\hline \hline \multicolumn{5}{c}{ Effects Specification } \\
\hline \hline
\end{tabular}

Cross-section fixed (dummy variables)

\begin{tabular}{lrll}
\hline \hline R-squared & 0.283827 & Mean dependent var & 0.997054 \\
Adjusted R-squared & 0.092848 & S.D. dependent var & 0.739058 \\
S.E. of regression & 0.703913 & Akaike info criterion & 2.325335 \\
Sum squared resid & 44.59436 & Schwarz criterion & 2.922059 \\
Log likelihood & -108.7068 & Hannan-Quinn criter. & 2.567542 \\
F-statistic & 1.486168 & Durbin-Watson stat & 2.210473 \\
Prob(F-statistic) & 0.093256 & & \\
\hline
\end{tabular}

Sumber : Output Eviews

Analisis regresi linear data panel pada penelitian ini menggunakan metode Fixed Effect. Pemilihan model Fixed Effectsebagai metode analisis data panel yang paling tepat untuk menguji data panel pada penelitian ini. Dari hasil regresi pada model Fixed Effectdidapatkan bahwa nilai koefisien kualitas audit sebesar 0,039752 dengan parameter positif $(+)$ dan nilai koefisien proporsi dewan komisaris independen sebesar $-4,009823$ dengan parameter negatif (-) dan dengan nilai R-Square sebesar 0.283827 (28\%) menjelaskan bahwa kualitas audit dan proporsi dewan komisaris independen mampu menjelaskan kinerja keuangan sebesar $28 \%$ dan sisanya $72 \%$ dijelaskan oleh variabel lain yang tidak terdapat dalam model ini. Nilai probabilitas kualitas audit sebesar 0.1618 tidak berpengaruh signifikan, karena besar dari alpha 5\% (0.1618>0.05), dan nilai probabilitas proporsi dewan komisaris independen sebesar 0.0291 berpengaruh signifikan, karena kecil dari alpha 5\% (0.0291 > 0.05).

\section{Hasil Uji Hipotesis}

Uji ini bertujuan untuk melihat variabel bebas mana yang memiliki pengaruh secara parsial terhadap variabel terikat dan sekaligus pengujian 
hipotesis. Dengan melihat nilai t hitung atau tingkat signifikansi setiap variabel. Dalam pengujian ini, alat ukur yang digunakan adalah nilai t hitung yang harus lebih besar dari t tabel atau probabilitas nilai signifikansi yang lebih kecil dari 0,05. Berdasarkan tabel 4.7 untuk hipotesis pertama diperoleh nilai $t_{\text {hitung }} 1,4107$ $<\mathrm{t}_{\text {tabel }} 1,981$ dengan nilai probabilitas $0,1618>$ alpha 0,05 akibatnya $\mathrm{H}_{0}$ diterima atau $\mathrm{H}_{\mathrm{a}}$ ditolak. Sehingga alternatif yang diajukan dalam penelitian ini terbukti ditolak. Sedangkan untuk hipotesis kedua pada penelitian ini diperoleh nilai $t_{\text {hitung }}$ $-2,2176<\mathrm{t}_{\text {tabel }} 1,981$ dengan probabilitas $0.0291<$ alpha 0,05 akibatnya $\mathrm{H}_{0}$ dit0lak atau $\mathrm{H}_{\mathrm{a}}$ diterima. Sehingga alternatif yang diajukan dalam penelitian ini terbukti diterima.

\section{PEMBAHASAN}

\section{Pengaruh Pelaksanaan Kualitas Audit terhadap Kinerja Keuangan}

Hasil pengujian hipotesis pertama menunjukkan bahwa variabel kualitas audit tidak berpengaruh terhadap kinerja keuangan yang tercermin pada Return On Equity(ROE) yang dilihat dari nilai probabilitas sebesar 0,1618 yang besar dari 0,05 . Hal tersebut menunjukkan bahwa kualitas audit memiliki pengaruh positif dan tidak signifikan terhadap kinerja keuangan. Arah positif menunjukkan ada kecenderungan bahwa semakin tinggi tingkat kualitas audit menunjukkan semakin tinggi keahlian auditor (spesialisasi) maka semakin tinggi pula tingkat integritas laporan keuangan, dan semakin baik juga laporan keuangan .

Dalam teori agensi yang mengasumsikan bahwa manusia itu selalu self interest, maka kehadiran pihak ketiga yang independen sebagai mediator pada hubungan antara prinsipal dan agen sangat diperlukan, dalam hal ini adalah auditor independen. Investor akan lebih cenderung pada data akuntansi yang dihasilkan dari kualitas audit yang tinggi (Hardiningsih, 2010). Auditor yang memiliki banyak klien dalam industri yang sama akan memiliki pemahaman yang lebih dalam tentang risiko audit khusus yang mewakiliindustri tersebut, tetap akanmembutuhkan pengembangan keahlian lebih daripada auditor pada umumnya. Tambahan keahlian ini akan menghasilkan return positif dalam fee audit, sehingga para peneliti memiliki hipotesis bahwa auditor dengan konsentrasi tinggi dalam industri tertentu akan memberikan kualitasyang lebih tinggi.

Hasil penelitian ini sesuai dengan penelitian yang dilakukanHardiningsih (2010), tentang pengaruh independensi, corporate governance dan kualitas audit terhadap integritas laporan keuangan perusahaan yang terdaftar di Bursa Efek Indonesia tahun 2005-2008. Hasil menunjukkan bahwa kualitas audit tidak berpengaruh terhadap integritas laporan keuangan.

\section{Pengaruh Proporsi Dewan Komisaris Independen terhadap Kinerja Keuangan}

Hasil uji hipotesis kedua menunjukkan bahwa proporsi dewan komisaris independen berpengaruh negatif dan signifikan terhadap kinerja keuangan yang tercermin pada Return On Equity(ROE). Hal ini dapat diketahui melalui nilai probabilitas sebesar 0.0291 yang lebih kecil dari 0,05 dapat diartikan bahwa pengaruh proporsi dewan komisaris independen terhadap kinerja keuangan yang 
tercermin pada return on equity tetap ada tetapi tanda negatif berarti akan berdampak terhadap kinerja keuangan.

Besarnya proporsi komisaris independen tidak mempengaruhi kinerja perusahaan. Kenaikan dan penurunan kinerja perusahaan lebih dipengaruhi oleh faktor lain selain proporsi komisaris independen (Susanti, 2011). Komisaris independen bertindak sebagai penengah dalam perselisihan yang terjadi di antara manajer internal dan mengawasi kebijakan manajemen serta memberikan nasihat kepada manajemen. Pengawasan yang dilakukan oleh dewan komisaris independen dapat meningkatkan kinerja manajer sehingga dapat memungkinkan kinerja perusahaan juga akan meningkat (Widyati, 2013).

Penelitian ini sejalan dengan Kusdiyanto \& Kusumaningrum (2015) tentang pengaruh good corporate governance dan laverage terhadap kinerja keuangan (studi pada perusahaan manufaktur yang tedaftar di BEI 2013-2014). Hasil penelitian menunjukkan bahwa proporsi komisaris independen memiliki pengaruh yang negatif signifikan terhadap kinerja keuangan perusahaan. Didukung dengan penelitian Djazilah \& Kurnia (2016) tentang pengaruh mekanisme GCG dan pengungkapan CSR terhadap kinerja keuanganpada perusahaan manufaktur yang terdaftar di Bursa Efek Indonesia tahun 2012-2014. Hasil penelitian menunjukkan bahwa proporsi dewan komisaris independen memiliki pengaruh signifikan terhadap kinerja yang tercermin pada return on equity. Dan juga penelitian (Dewi, 2012) tentang pengaruh corporate governance dan laverage terhadap kinerja keuangan pada perbankan yang tedaftar di BEI. Hasil penelitian menunjukkan bahwa proporsi komisaris independen memiliki pengaruh yang negatif signifikan terhadap kinerja keuangan perusahaan.

\section{SIMPULAN}

Berdasarkan hasil penelitian yang telah dilakukan tentang avriabel kualitas audit $\left(\mathrm{X}_{1}\right)$ dan proporsi dewan komisaris independen $\left(\mathrm{X}_{2}\right)$ terhadap variabel kinerja keuangan (Y) maka dapat ditarik kesimpulan sebagai berikut :

1. Kualitas audit berpengaruh positif dan tidak signifikan terhadap return on equity dengan nilai siggnifikan $0.1618>0,05$ dan nilai thitung lebih besar dari tabel maka $\mathrm{H}_{0}$ diterima atau $\mathrm{H}_{\mathrm{a}}$ ditolak.

2. Proporsi dewan komisaris independen berpengaruh negatif dan signifikan terhadap return on equity dengan nilai probabilitas $0,0291<0,05 t_{\text {hitung }}$ lebih kecil dari $\mathrm{t}_{\text {tabel }}$ maka $\mathrm{H}_{0}$ ditolak atau $\mathrm{H}_{\mathrm{a}}$ diterima.

\section{DAFTAR PUSTAKA}

Andriza, R., \& Yusra, I. (2019). Pengaruh kepemilikan manajerial dan kebijakan deviden terhadap kemakmuran Investor dan nilai perusahaan yang tercatat pada indeks LQ45. INA-Rxiv.

Angraini, I., \& Yusra, I. (2019). Pendekatan data panel terhadap return saham: studi empiris pada perusahaan LQ45. INA-Rxiv.

Aziz, A., \& Hartono, U. (2017). Pengaruh Good Corporate Governance, Struktur Modal, dan Leverage Terhadap Kinerja Keuangan Perusahaan Pada Sektor 
Pertambangan yang Terdaftar di Bursa Efek Indonesia Tahun 2011-2015. Jurnal Lmu Manajemen, 5(3), 1-13.

Christiani, I., \& Nugrahanti, Y. W. (2014). Pengaruh Kualitas Audit Terhadap Manajemen Laba. Jurnal Akuntansi Dan Keuangan, 16(1), 52-62. https://doi.org/10.9744/jak.16.1.52-62

Danil, A., \& Yusra, I. (2019). Pengaruh kausal antara ukuran perusahaan, nilai buku dan likuiditas saham di Bursa Efek Indonesia. INA-Rxiv.

Dewi, A. S. (2012). Pengaruh Corporate Governance dan Laverage Terhadap Kinerja Keuangan pada Perbankan yang Terdaftar di BEI. Kajian Akuntansi Dan Auditing, 7(1), 61-71.

Djazilah, R., \& Kurnia. (2016). Pengaruh Mekanisme GCG Dan Pengungkapan CSR Terhadap Kinerja Keuangan. Jurnal Ilmu Dan Riset Akuntansi, 5(10), $1-19$.

Eva, E., \& Artinah, B. (2016). Pengaruh Pelaksanaan Good Corporate Governance, Kepemilikan Institutional Dan Laverage Terhadap Kinerja Keuangan (Studi Pada Industri Perbankan Di Bursa Efek Indonesia). Manajemen Dan Akuntansi, 17(April), 17-28.

Fahruri, A. (2017). Pengaruh Corporate Governance, Loan to Deposit Ratio, Non Performing Loan, Inflasi dan Kurs Terhadap Kinerja Keuangan Perusahaan Perbankan yang Terdaftar di Bursa Efek Indonesia pada Tahun 2007-2010, $X V(1), 63-70$.

Gusnita, E., \& Martha, L. (2019). Analisis Struktur Modal Dalam Memoderasi Pengaruh Kepemilikan Manajerial Dan Pertumbuhan Perusahaan Terhadap Nilai Perusahaan Di Indonesia. INA-Rxiv.

Hadya, R. (2014b). Earning Surprise, Ketepatan Waktu Pengumuman Laporan Keuangan Dan Reaksi Pasar. Jurnal Riset Manajemen Dan Akuntansi, 1(2).

Hadya, R., Begawati, N., \& Yusra, I. (2017). Analisis Efektivitas Pengendalian Biaya, Perputaran Modal Kerja, dan Rentabilitas Ekonomi Menggunakan Regresi Data Panel. Jurnal Pundi, 01(03), 1-35.

Hanafi, D., \& Yusra, I. (2019). Tangibility, liquidity, growth opportunity, dan leverage: studi pada perusahaan terdaftar di Bursa Efek Indonesia. INA-Rxiv, (2001).

Handayani, F., \& Martha, L. (2019). Hubungan Antara Profitabilitas Dengan Nilai Perusahaan Yang Dimoderasi Oleh Corporate Social Responsibility. INARxiv.

Hardiningsih, P. (2010). Pengaruh Independensi, Corporate Governance, Dan Kualitas Audit Terhadap Integritas Laporan Keuangan. Jurnal Kajian Akuntansi, 2(1), 61-76.

Hasanah, I., Susyanti, J., \& Wahono, B. (2017). Analisis Kinerja Keuangan 
Perusahaan Real Estate Dan Property Yang Terdaftar Di Bursa Efek Indonesia Sebelum Dan Selama Pemerintahan Presiden Jokowi. Jurnal Warta Ekonomi, 7(17), 47-63.

Kartin, Y. R., \& Dewi, A. S. (2019). Karakteristik Dewan Komisaris Dan Dampaknya Terhadap Kinerja Keuangan. INA-Rxiv.

Kusdiyanto, \& Kusmaningrum, D. D. (2015). Pengaruh Good Corporate Governance Dan Laverage Terhadap Kinerja Keuangan (Studi Pada Perusahaan Manufaktur Yang Tedaftar Di BEI 2013-2014). Jurnal Managemen Dan Bisnis, 19(2), 161-167.

Laili, E. S., \& Dewi, A. S. (2019). Dampak Kinerja Keuangan terhadap Corporate Social Responbility pada Sektor Perbankan di Indonesia. INA-Rxiv.

Martha, L. (2018). Peranan Analisis Laporan Keuangan terhadap Pengambilan Keputusan Pemberian Kredit Pada PT. BPR LPN Sungai Rumbai Kabupaten Dharmasraya. INA-Rxiv.

Mulfita, A., \& Yusra, I. (2019). Analisis regresi data panel terhadap likuiditas saham di Indonesia. INA-Rxiv.

Monica, S., \& Dewi, A. S. (2019). Pengaruh Kepemilikan Institusional dan Dewan Komisaris Independen Terhadap Kinerja Keuangan di Bursa Efek Indonesia. INA-Rxiv.

Perdana, H. D., Putra, R. P., \& Murni, S. (2016). Corporate Governance Dan Kinerja Keuangan Perusahaan (Studi pada Perusahaan Indonesia di Indeks LQ45 Tahun 2010-2014). Jurnal Akuntansi, 4(1), 1-10.

Putra, I., \& Yusra, I. (2019). Analisis likuiditas saham menggunakan regresi data panel. INA-Rxiv.

Rahmawati, N., \& Asyikin, J. (2016). Pengaruh Corporate Governance Perception Index Terhadap Kinerja Keuangan Perusahaan Yang Terdaftar Di Bursa Efek Indonesia Periode 2009-2013. Jurnal Manajemen Dan Akuntanti, 17(April), 53-66.

Saputra, J., \& Martha, L. (2019). Analisis Kinerja Keuangan Dan Nilai Perusahaan, Serta Pengaruhnya Terhadap Harga Saham. INA-Rxiv.

Setiawan, B. (2015). Pengaruh Independensi, Kualitas Audit dan Mekanisme Corporate Governance Terhadap Integritas Laporan Keuangan Perusahaan Manufaktur di Bursa Efek Indonesia tahun 2008-2012. Jom FEKON, 2(2), 115.

Sugiyono. (2015). Statistik Nonpaametris Untuk Penelitian. (B. R. Setiadi, Ed.). Yogyakarta: Penerbit Alfabeta Bandung.

Suhartono, \& Yusra, I. (2019). Analisis perbandingan kinerja keuangan bank konvensional dengan bank syariah yang terdaftar di BEI. INA-Rxiv, 1-9. 
Susanti, S. I. A. (2011). Pengaruh Kualitas Corporate Governance, Kualitas Audit, dan Earning Management Terhadap Kinerja Perusahaan. Junal Ekonomi Dan Bisnis, 5(2), 145-161.

Sutrisno. (2012). Manajemen Keuangan: Teori Konsep \& Aplikasi (1st ed.). Yogyakarta: Penerbit Ekonisia.

Wahyudi, R., \& Martha, L. (2019). Analisis Modal Intelektual Dan Kinerja Keuangan Dan Pengaruhnya Terhadap Nilai Perusahaan. INA-Rxiv.

Widyati, M. F. (2013). Pengaruh Dewan Direksi, Komisaris Independen, Komite Audit, Kepemilikan Manajerial Dan Kepemilikan Institutional Terhadap Kinerja Keuangan. Jurnal Ilmu Manajemen, 1(1), 234-249.

Winarno, W. W. (2015). Analisis Ekonometrika dam Statistika dengan EViews (4th ed.). Yogyakarta: UPP STIM YKPN.

Yusra, I., Hadya, R., Begawati, N., \& Istiqomah, L. (2019). Panel data model estimation: the effect of managerial ownership, capital structure, and company size on corporate value Panel data model estimation : the effect of managerial ownership, capital structure, and company size on corporate value. Journal of Physics: Conference Series, 1175, 1-6. https://doi.org/10.1088/1742-6596/1175/1/012285 